\title{
PENERAPAN PASAL 4 UNDANG-UNDANG NO.8 TAHUN 1999 TENTANG PERLINDUNGAN KONSUMEN PADA JASA PENGIRIMAN DOKUMEN DI PT. KERTA GAYA PUSAKA PERWAKILAN PURWOKERTO*
}

\author{
Oleh: \\ Rochani Urip Salami, I Ketut Karmi Nurjaya, dan Krisnhoe Kartika \\ Fakultas Hukum Universitas Jenderal Soedirman
}

\begin{abstract}
Nowadays, the issue of consumer protection in Indonesia has encompassed various fields of social life, nd without any exemption, the isuue of transportation is include thereof. Transportation is one of the factor that able to determine the succes of state's economic. Transportation is executable through land, air and water. One of the forms of services in land transportation is the transport of package in Purwokerto that run the area of document. This research usesd the method of normative approach, eith the intention to conclude the legal protection toward the consumer of PT Kerta Gaya Pustaka package transport service branch in Purwokerto, considering that PT Kerta Gaya Pustaka is one of the parties in the world of bussiness that has obligations to perform its bussiness in conformity with the principles and provisions in the consumer protection act (UUPK) as well as possible and with liabilities.
\end{abstract}

Kata Kunci : Perlindungan Konsumen, jasa Pengiriman dokumen

\section{A. Pendahuluan}

Pembangunan dan perekonomian umumnya dan khususnya di bidang perindustrian dan perdagangan nasional telah menghasilkan berbagai variasi barang dan/atau jasa. Di samping itu globalisasi dan perdagangan bebas yang didukung oleh kemajuan teknologi, telekomunikasi, dan informatika telah memperluas ruang gerak arus transaksi barang dan/atau jasa yang ditawarkan bervariasi.

Kondisi yang demikian pada satu pihak mempunyai manfaat bagi konsumen karena kebutuhan konsumen akan barang dan/atau jasa yang diinginkan dapat terpenuhi, serta dapat terbuka lebar kebebasan untuk memilih aneka jenis dan kualitas barang dan/atau jasa yang sesuai dengan keinginan dan kemampuan konsumen. Di sisi lain dengan adanya keterbukaan/kebebasan seperti itu, maka akan semakin meningkatkan permasalahan di bidang perlindungan konsumen.

Perlindungan konsumen merupakan permasalahan kepentingan manusia, oleh karenanya menjadi harapan bagi semua bangsa di

\footnotetext{
* Artikel ini merupakan artikel hasil penelitian dari penelitian yang dilakukan dengan Anggaran DIPA Unsoed 2007
}

dunia untuk dapat mewujudkan perlindungan konsumen dalam hubungannya dengan berbagai dimensi yang satu sama lain mempunyai keterkaitan dan saling ketergantungan antara konsumen, pengusaha dan pemerintah.

Dalam kaitan ini, perlindungan konsumen dipandang secara formil maupun mateeriil semakin terasa sangat penting, mengingat semakin lajunya ilmu pengetahuan dan teknologi yang merupakan motor penggerak bagi produktivitas dan efisiensi produsen atas barang dan/atau jasa yang dihasilkan dalam rangka mencapai sasaran usaha. Dalam rangka mengejar dan mencapai kedua hal tersebut, akhirnya baik langsung maupun tidak langsung, maka konsumenlah yang pada umumnya akan merasakan dampaknya.

Kebutuhan konsumen akan barang dan/ atau jasa semakin meningkat dengan berkembangnya pembangunan pada saat ini. Salah satu kebutuhan konsumen yang berkaitan dengan jasa adalah jasa angkutan. Pengangkutan dapat dikatakan sebagai sarana yang sangat vital, baik dalam kaitannya dengan pengangkutan konsumensebagai penumpang maupun pada saat konsumen akan mengirimkan barang. 
Pengertian pengangkutan terdapat dalam Pasal 1 angka (2) undang-Undang Nomor 14 Tahun 1992 tentang Angkutan jalan dan lalu Lintas Jalan yang menyebutkan bahwa angkutan adalah perpindahan orang dan/atau barang dri suatu tempat tujuan ke tempat lain dengan menggunakan kendaraan. Sedangkan pengertian pengangkutan menurut Abdul Kadir Muhammad adalah :

Pengangkutan adalah proses kegiatan memuat barang atau penumpang ke dalam alat pengangkutan, membawa barang atau penumpang dari tempat pemuatan ke tempat tujuan dan menurunkan barang atau penumpang dari alat pengangkutan ke tempat yang ditentukan.

Pengangkutan dapat dilakukan di darat, udara dan laut. Khusus mengenai pengangkutan darat, pengangkutan barang di darat diatur di dalam Kitab Undang-Undang Hukum Dagang (KUHD) Buku I Bab V Bagian II dan Bagian III mulai dari Pasal 90 sampai dengan Pasal 98, namun ketentuan tersebut hanya diberikan sedikit saja yaitu secara sumir. ${ }^{2}$

Salah satu bentuk pengangkutan barang di darat adalah pengangkutan barang paket. Pengertian paket menurut Pasal 1 angka (6) Undang-Undang Nomor 6 Tahun 1984 Tentang Pos ialah :

Kemasan yang berisi barang dengan bentuk dan ukuran tertentu. Pelayanan paket dapat dilakukan oleh instansi negara yaitu melalui kantor pos ataupun juga melalui perusahaan swasta yang bergerak di bidang pengiriman paket.

Di Purwokerto sendiri, salah satu contoh perusahaan swasta yang bergerak di bidang usaha pelayanan kiriman paket adalah PT. Kerta Gaya Pusaka. Perusahaan ini selain melayani pengiriman paket, juga melayani pengiriman dokumen-dokumen perusahaan yang biasanya telah menjadi relasi mereka.

Abdulkadir Muhammad, 1991, Hukum Pengakutan Darat, laut dan Udara, Bandung: Citra Aditya Bakti, hlm.19

2 Soekardono, 1986, Hukum Dagang Indonesia Jilid II, Jakarta: CV.Rajawali, hlm.2. Lihat juga Soegiyatna Tjakranegara, 1995, Hukum Pengangkutan Barang dan Penumpang, Jakarta: Rineka Cipta, hlm.1
Pada penyelenggaraan pengangkutan dokumen dapat terjadi peristiwa-peristiwa yang mengakibatkan kerusakan, keterlambatan, atau pun hilangnya dokumen yang diangkut. Akibat adanya kerusakan, kehilangan, atau keterlambatan tersebut maka dapat merugikan si pengirim maupun penerima. ${ }^{3}$ Oleh karena itu, apabila seseorang mempercayakan pengiriman dokumen kepada sebuah perusahaan pelayanan pengiriman paket maka berdasarkan perjanjian yang dibuatnya, si pengirim berkedudukan sebagai konsumen yang harus dilindungi hakhaknya oleh perusahaan pelayanan pengiriman paket yang berkedudukan sebagai pelaku usaha.

\section{B. Perumusan Masalah}

Berdasarkan pendahuluan di atas, maka dirumuskan masalah berupa bagaimanakah perlindungan hukum terhadap konsumen jasa pengiriman dokumen di PT. Kerta Gaya Pusaka Perwakilan Purwokerto?

\section{Metode Penelitian}

Penelitian ini menggunakan metode pendekatan yuridis normatif dengan spesifikasi penelitian berupa penelitian deskriptif. Lokasi penelitian di PT. Kerta Gaya Pustaka Perwakilan Purwokerto. Sumber data yang digunakan berupa data sekunder yang dilengkapi dengan data primer. Data diperoleh melalui penelusuran literatur dan wawancara dengan pihak PT. Kerta Gaya Pusaka Purwokerto. Data yang diperoleh dianalisis dengan metode análisis data kualitatif dan disajikan dalam bentuk uraian yang disusun secara sistematis.

\section{Pembahasan}

Pengertian konsumen berasal dari bahasa Belanda konsument diartikan oleh para ahli sebagai pemakai terakhir barang dan jasa yang diserahkan kepada mereka oleh para pengusaha baik oleh pengusaha itu sebagai produsen maupun pedagang perantara. ${ }^{4}$

\footnotetext{
3 Muhammad, Abdulkadir, 1982, Hukum Perikatan, Bandung: Alumni, hlm.16

4 A.Z. Nasution, 2002, Hukum Perlindungan Konsumen; Suatu Pengantar, Jakarta: Diadit Media, hlm.3
} 
Penerapan Pasal 4 UU No.8 Tahun 1999 Tentang Perlindungan 147 Konsumen Pada Jasa Pengiriman Dokumen ...

Sidharta berpendapat bahwa:

Konsumen memang tidak sekedar pembeli (buyer atau koper), tetapi semua orang (perorangan atau badan usaha) yang mengkonsumsi jasa dan/atau barang. Jadi, yang paling penting terjadinyasuatu transaksi konsumen (consumer transaction) berupa peralihan barang dan/ atau jasa, termasuk peralihan kenikmatan dalam menggunakannya. ${ }^{5}$

Pengertian konsumen menurut UUPK Pasal 1 angka (2) adalah :

Setiap orang pemakai barang dan/atau jasa yang tersedia dalam masyarakat baik bagi kepentingsn diri sendiri, keluarga, orang lain, mahkluk hidup lain dan tidak untuk diperdagangkan.

Pasal 1 angka (10) UU Nomor 14 Tahun 1992 tentang Lalu Lintas dan Angkutan Jalan menyebutkan bahwa :

Pengguna jasa adalah setiap orang dan/ atau badan hukum yang menggunakan jasa angkutan, baik untuk angkutan orang maupun angkutan barang.

Atas dasar pengertian konsumen yang disebut dalam Pasal 1 angka (2) UUPK, Pasal 1 angka (10) UU Nomor 14 Tahun 1992, A.Z. Nasution berpendapat, apabila dikaitkan dengan pengertian konsumen yang tersirat dalam konosemen, jelas mendeskripsikan bahwa konsumen tersebut adalah termasuk dalam kategori konsumen yang berhak memperoleh perlindungan hukum berdasarkan UUPK. ${ }^{6}$

Penyelenggaraan jasa pengiriman dokumen tidak terlepas dari pelaku usaha atau badan penyelenggara. Dalam Pasal 1 angka (3) UUPK, yang dimaksud dengan pelaku usaha adalah :

Pelaku usaha adalah setiap orang perorangan atau badan usaha, baik yang berbentuk badan hukum maupun bukan badan hukum yang didirikan dan berkedudukan atau melakukan kegiatan dalam wilayah hukum Negara republik Indonesia, baik sendiri maupun bersamasama melalui perjanjian menyelenggara-

5 Shidarta, 2004, Perlindungan Konsumen Indonesia, Jakarta: PT. Gramedia Widiasarana Indonesia, hlm.7

6 A.Z. Nasution, Op.cit, hlm.5 kan kegiatan usaha dalam berbagai bidang ekonomi.

Berdasarkan penjelasan Pasal 1 angka (3) UUPK disebutkan bahwa pelaku usaha yang dalam pengertian tersebut adalah perusahaan, koorporasi, BUMN, importir, pedagang distributor, dan lain-lain.

Definisi pelaku usaha yang diberikan dalam UUPK itu mencakup pelaku usaha secara luas. Para pelaku usaha yang dimaksud dalam Undang-Undang Perlindungan Konsumen tersebut tidak hanya dibatasi pada pabrikan saja, melainkan juga bagi para distributor (dan jaringannya), serta termasuk para importir. Selain itu, para pelaku usaha periklananpun tunduk pada ketentuan Undang-Undang ini.

Pasal 1 angka (8) Undang-Undang Nomor 14 Tahun 1992 Tentang Lalu Lintas dan Angkutan jalan menyebutkan bahwa :

Perusahaan angkutan umum adalah perusahaan yang menyediakan jasa angkutan orang dan/atau barang dengan kendaraan umum di jalan.

Pasal 2 Peraturan Menteri Perhubungan Nomor KM 5 Tahun 2005 Tentang Penyelenggaraan Jasa Titipan menyebutkan bahwa :

Penyelenggaraan jasa titipan adalah kegiatan yang dilakukan untuk menerima, membawa dan/atau menyampaikan paket, uang dan surat pos jenis tertentu dalam bentuk barang cetakan, surat kabar, sekogram, bungkusan kecil dari pengirim kepada penerima dengan memungut biaya.

Mencermati pihak pelaku usaha bila dikaitkan dengan pengertian pelaku usaha Pasal 1 angka (3) UUPK dan penjelasannya, pengertian perusahaan angkutan umum dalam Pasal 1 angka (8) UU Tentang Lalu Lintas dan Angkutan Jalan, Pasal 2 Peraturan Menteri Perhubungan No.KM 5 Tahun 2005 Tentang Penyelenggaraan Jasa Titipan serta pendapat dari Gunawan Widjaja dan Ahmad Yani, mendeskripsikan bahwa PT. Kerta Gaya Pusaka Perwakilan Purwokerto adalah sebagai pelaku usaha yang menyelenggarakan jasa titipan, termasuk didalamnya adalah pengiriman dokumen. 
Penerapan Pasal 4 Undang-Undang No.8 Tahun 1999 Tentang Perlindungan konsumen pada dasarnya merupakan upaya untuk memberikan perlindungan kepada konsumen.

Hak-Hak konsumen yang dimaksud dalam Pasal tersebut di atas adlah :

a. Hak atas kenyamanan, keamanan, dan keselamatandalam mengkonsumsi barang dan/atau jasa;

b. Hak untuk memilih barang dan/atau jasa serta mendapatkan barang dan/ atau jasa tersebut sesuai dengan nilai tukar dan kondisi serta yang dijanjikan;

c. Hak atas informasi yang benar,jelas, dan jujur mengenai kondisi dan jaminan barang dan/atau jasa;

d. Hak untuk didengar pendapat dan keluhannya atas barang dan/atau jasa yang digunakan;

e. Hak untuk mendapatkan advokasi, perlindungan, dan upaya penyelesaian sengketa perlindungan konsumen secara patut;

f. Hak untuk mendapatkan pembinaan dan pendidikan konsumen;

g. Hak untuk diperlakukan atau dilayani secara benardan jujur serta tidak diskriminatif;

h. Hak untuk mendapatkan kompensasi ganti rugi dan/atau penggantian apabila barang dan/atau jasa yang diterima tidak sesuai dengan perjanjian atau tidak sebagaimana mestinya;

i. Hak-hak yang diatur dalam ketentuan peraturan perundang-undangan lainnya. ${ }^{7}$

1. Hak atas kenyamanan, keamanan, dan keselamatandalam mengkonsumsi barang dan/atau jasa;

Dari sembilan butir hak konsumen yang diberikan diatas, terlihat bahwa masalah kenyamanan, keamanan, dan keselamatan konsumen merupakan hal yang paling pokok dan utama dalam perlindungan konsumen. Barang

\footnotetext{
7 Setiawan R, 1999, Pokok-Pokok Perikatan, Bandung: Putra Bardin, hlm.17
}

dan/atau jasa yang penggunaannya tidak memberikan kenyamanan, terlebih lagi yang tidak aman atau membahayakan keselamatan konsumen jelas tidak layak untuk diedarkan dalam masyarakat. Selanjutnya, untuk menjamin bahwa suatu barang dan/atau jasa dalam penggunaannya akan nyaman, aman maupun tidak membahayakan konsumen peng-gunanya, maka konsumen diberikan hak untuk memilih barang dan/atau jasa yang dikehendakinya berdasarkan atas keterbukaan informasi yang benar, jelas, dan jujur. Jika terdapat penyimpangan yang merugikan, konsumen berhak untuk didengar, memperoleh advokasi, pembinaan, perlakuan yang adil, kompensasi ganti kerugian. ${ }^{8}$

Menurut pendapat Shidarta, konsumen berhak mendapatkan keamanan dari barang dan jasa yang ditawarkan kepadanya. Produk barang dan jasa itu tidak boleh membahayakan jika dikonsumsi sehingga konsumen tidak dirugikan baik secara jasmani dan rohani. ${ }^{9}$

Ahmadi Miru mengemukakan bahwa hak atas keamanan dan keselamatan ini dimaksudkan untuk menjamin keamanan dan keselamatan konsumen dalam penggunaan barang dan/atau jasa yang diperolehnya, sehingga konsumen dapat terhindar dari kerugian (fisik maupun psikis) apabila mengkonsumsi suatu produk. ${ }^{10}$

Berdasarkan pada kewajiban pengangkut dan tentang tanggung jawab pengangkut, jika diakitkan dengan pendapat Gunawan Widjaja dan Ahmad Yani, shidarta dan Ahmadi Miru diatas dapat dideskripsikan bahwa PT. Kerta Gaya Pusaka Perwakilan Purwokerto dalam memberikan pelayanan kepada pengguna jasa telah memenuhi ketentuan Pasal 4 butir a UUPK tentang hak konsumen atas kenyamanan, keamanan, dan keselamatan dalam mengkonsumsi barang dan/atau jasa.

\footnotetext{
8 Ahmad Yani dan Gunawan Widjaya, 2003, Hukum Tentang Perlindungan Konsumen, Jakarta: PT. Gramedia Pustaka Utama, hlm.10

9 Sidharta, Op.cit, hlm.22

${ }^{10}$ Ahmadi Miru dan Sutarman Yodo, 2004, Hukum Perlindungan Konsumen, Jakarta: PT. Gaja Grafindo Persada, hlm.41
} 
2. Hak untuk memilih barang dan/atau jasa serta mendapatkan barang dan/atau jasa tersebut sesuai dengan nilai tukar dan kondisi serta yang dijanjikan

Hak untuk memilih tersebut merupakan hak dasar yang tidak dapat dihapuskan oleh siapapun juga. Melalui hak pilinnya tersebut, konsumen dapat menentukan cocok tidaknya suatu barang dan/atau jasa yang ditawarkan atau diperdagangkan dengan kebutuhan.

Ahmadi Miru dan Sutarman Yodo berpendapat bahwa:

Hak untuk memilih produk-produk tertentu sesuai dengan kebutuhannya, tanpa ada tekanan dari pihak luar. Berdasarkan hak untuk memilih ini konsumen berhak memutuskan untuk membeli atau tidak terhadap suatu produk, demikian pula keputusan untuk memilih baik kualitas maupun kuantitas jenis produk yang dipilihnya. ${ }^{11}$

Dalam mengkonsumsi suatu produk, konsumen berhak menentukan pilihannya. la tidak boleh mendapat tekanan dari pihak luar sehingga ia tidak lagi bebas untuk membeli atau tidak membeli. Seandainya ia jadi membeli, ia juga bebas menentukan produk mana yang akan dibeli.

Sudaryatmo mempunyai pendapat tentang hak untuk memilih :

Salah satu faktor dominan yang menempatkan konsumen dalam posisi lemah adalah belum adanya kesadaran konsumen akan hak-haknya. Namun demikian, adanya kesadaran konsumen tidak otomatis menempatkan konsumen dalam posisi yang kuat. Dalam kasus-kasus komoditas yang dikelola secara monopolistik, sehingga menempatkan konsumen dalam posisi tidak ada pilihan, sekritis apapun konsumen, tetap akan berada pada posisi yang lemah. Untuk itu, idealnya konsumen diberi kebebasan untuk memilih suatu barang atau jasa. Untuk dapat memilih, harus ada pilihan (pelaku usaha lebih dari satu), sehingga konsumen dapat melakukan perbandingan tentang kualitas dan harga suatu produk

\footnotetext{
${ }^{11} \mathrm{lbid}, \mathrm{hlm} .42$
}

atau jasa, sebelum menjatuhkan pilihannya. ${ }^{12}$

Berdasarkan tentang perjanjian antara konsumen dengan PT. Kerta Gaya Pusaka ditandai dengan dilakukannya penanda-tanganan konosemen oleh konsumen yang bersedia mentaati isian dan syarat-syarat pengiriman, tentang tarif pengiriman dokumen, dalam hal ini konsumen telah memilih jasa yang diberikan PT. Kerta Gaya Pusaka dan tidak ada unsur paksaan dari luar. Berdasarkan hal tersebut maka, telah sejalan dengan ketentuan Pasal 4 butir b UUPK tentang hak konsumen untuk memilih barang dan/atau jasa serta mendapatkan barang dan/atau jasa tersebut sesuai dengan nilai tukar dan kondisi serta jaminan yang dijanjikan.

3. Hak atas informasi yang benar,jelas, dan jujur mengenai kondisi dan jaminan barang dan/atau jasa

Setiap konsumen tentu saja tidak menginginkan menderita kerugian akibat mengkonsumsi suatu barang dan/atau jasa. Informasi yang jelas dan benar tentang suatu barang dan/atau jasa mutlak diberikan kepada konsumen oleh pelaku usaha yang menyediakan barang dan/atau jasa.

Menurut Shidarta mengenai hak untuk mendapatkan informasi yang benar bahwa:

Setiap produk yang diperkenalkan kepada konsumen harus disertai informasi yang benar. Informasi ini diperlukan agar konsumen tidak sampai mempunyai gambaran yang keliru atas produk barang dan jasa. Informasi ini dapat disampaikan dengan berbagai cara, seperti secara lisan kepada konsumen, melalui iklan di berbagai media, atau mencantumkan dalam kemasan produk (barang). ${ }^{13}$

Bagi konsumen, informasi tentang barang dan/atau jasa merupakan kebutuhan pokok, sebelum ia menggunakan sumber dananya (gaji, upah, honor, atau apapun nama lainnya) untuk mengadakan transaksi konsumen tentang barang dan/atau jasa.

\footnotetext{
${ }^{12}$ A.Z. Nasution, dkk, 2001, Liku-Liku Perjalanan UUPK, Jakarta: YLKI, hlm.7

${ }^{13}$ Sidharta, Op.cit, hlm.24
} 
Pasal 3 huruf d UUPK menyebutkan bahwa perlindungan konsumen bertujuan menciptakan sisitem perlindungan konsumen yang mengandung unsur kepastian hukum dan keterbukaan informasi serta akses untuk mendapatkan informasi. Dengan adanya unsur keterbukaan informasi serta akses untuk mendapatkan informasi dalam sistem perlindungan konsumen berarti adanya suatu hak yang harus dijanjikan oleh pelaku usaha untuk melindungi konsumen yaitu hak konsumen untuk mendapatkan keterbukaan informasi yang benar, jujur, mengenai kondisi dan jaminan barang dan/atau jasa yang dikonsumsi oleh konsumen.

Ahmadi Miru dan Sutarman Yodo berpendapat bahwa :

Hak atas informasi ini sangat penting, karena tidak memadainya informasi yang disampaikan kepada konsumen, ini dapat juga merupakan salah satu bentuk cacat produk, yaitu yang dikenal dengan cacat instruksi atau cacat karena informasi yang tidak memadai. Hak atas informasi yang jelas dan benar dimaksudkan agar konsumen dapat memperoleh gambaran yang benar tentang suatu produk, karena dengan informasi tersebut, konsumen dapat memlih produk yang diinginkan/ sesuai dengan kebutuhannya serta terhindar dari kerugian akibat kesalahan dalam penggunaan produk. ${ }^{14}$

Berdasarkan pada informasi tarif pengiriman, dan tentang tanggung jawab jika dikaitkan dengan pendapat Shidarta, A.Z Nasution dan Ahmadi Miru di atas maka dapat dideskripsikan bawa perlindungan terhadap hak konsumen atas informasi yang benar, jelas dan jujur mengenai kondisi dan jaminan jasa pengiriman paket telah sesuai dengan ketentuan Pasal 4 butir c UUPK.

4. Hak untuk didengar pendapat dan keluhannya atas barang dan/atau jasa yang digunakan

Ahmadi Miru dan Sutarman Yodo berpendapat bahwa :

Hak untuk didengar ini merupakan hak dari konsumen agar tidak dirugikan lebih

\footnotetext{
${ }^{14}$ Ahmadi Miru dan Sutarman Yodo, Op.cit, hlm.41
}

lanjut, atau hak untuk menghindarkan diri dari kerugian. Hak ini dapat berupa pertanyaan tentang berbagai hal yang berkaitan dengan produk-produk tertentu apabila informasi yang diperoleh tentang produk tersebut kurang memadai, ataukah berupa pernyataan/pendapat tentang suatu kebijakan pemerintah yang berkaitan dengan kepentingan konsumen. ${ }^{15}$

Berdasarkan pada kewajiban pengirim untuk melaporkan kepada pihak PT. Kerta Gaya Pusaka dalam waktu $2 \times 24$ jam terhitung mulai barang diterima, jika dikaitkan dengan pendapat Ahmadi Miru dan Sutarman Yodo dapat dideskripsikan bahwa penyelenggaraan jasa pengiriman paket telah sejalan dengan ketentuan Pasal 4 butir d UUPK.

5. Hak untuk mendapatkan advokasi, perlindungan,dan upaya penyelesaian sengketa perlindungan konsumen secara patut

Mengenai hak konsumen untuk mendapatkan advokasi dan upaya penyelesaian sengketa secara patut, pihak PT. Kerta Gaya Pusaka belum memiliki aturan secara tertulis. Berdasarkan pada hasil wawancara disebutkan bahwa dalam hal terjadi sengketa antara pihak pengirim/penerima dengan pihak PT. Kerta Gaya Pusaka Perwakilan Purwokerto, diselesaikan dengan cara kekeluargaan (musyawarah mufakat)hingga terjadi suatu kesepakatan diantara keduanya.

\section{Hak untuk mendapatkan pembinaan dan pendidikan konsumen \\ Menurut Ahmadi Miru dan Sutarman Yodo} bahwa :

Hak untuk memperoleh pendidikan konsumen ini dimaksudkan agar konsumen memperoleh pengetahuan maupun keterampilan yang diperlukan agar dapat terhindar dari kerugian akibat penggunaan produk, karena dengan pendidikan konsumen tersebut, konsumen akan dapat menjadi lebih kritis dan teliti

${ }^{15}$ Ibid, hlm. 43 
dalam memilih suatu produk yang dibutuhkan. ${ }^{16}$

Shidarta berpendapat tentang hak untuk mendapatkan pendidikan konsumen :

Masalah perlindungan konsumen di Indonesia termasuk masalah yang baru. Oleh karena itu, wajar bila masih banyak konsumen yang belum menyadari hakhaknya. Kesadaran akan hak tidak dapat dipungkiri sejalan dengan kesadaran hukum. Makin tinggi tingkat kesadaran hukum masyarakat, makin tinggi penghormatannya pada hak-hak dirinya dan orang lain. Dalam banyak hal, pelaku usaha terikat untuk memperhatikan hak konsumen untuk mendapatkan "pendidikan kon-sumen". ${ }^{17}$

PT. Kerta Gaya Pusaka Perwakilan Purwokerto dalam penyelenggaraan jasa pengiriman dokumen, belum memiliki aturan mengenai pemberian pembinaan dan pendidikan konsumen sehingga belum memenuhi ketentuan Pasal 4 butir $\mathrm{f}$ UUPK.

7. Hak untuk diperlakukan atau dilayani secara benardan jujur serta tidak diskriminatif

Menurut penjelasan Pasal 4 huruf g UUPK disebutkan bahwa hak untuk diperlakukan atau dilayani secara benar dan jujur serta tidak diskriminatif berdasarkan suku, agama, budaya, daerah, pendidikan, kaya, miskin, dan status sosialnya.

Pasal 43 UU Nomor 14 Tahun 1992 Tentang Lalu Lintas dan Angkutan Jalan menyebutkan bahwa :

Pengusaha angkutan umum wajib mengangkut orang dan/atau barang setelah disepakatinya perjanjian pengangkutan dan/atau dilakukan pembayaran biaya angkutan oleh penumpang dan/atau pengiriman barang.

Berdasarkan penelitian di PT. Kerta Gaya Pusaka Perwakilan Purwokerto belum ada aturan secara tertulis berkaitan dengan pelayanan secara benar dan jujur serta tidak diskriminatif, namun dalam prakteknya PT.

16 Ibid, hlm.44

17 Shidarta, Op.cit, hlm. 34
Kerta Gaya Pusaka dalam melaksanakan kewajibannya mempunyai komitmen bahwa siapapun yang menggunakan jasa pengiriman paket serta dokuman dan sanggup untuk mematuhi semua isian dan syarat-syarat pengiriman yang telah ditetapkan wajib diperlakukan dan dilayani dengan baik, dalam hal ini perlakuan yang tidak diskriminatif termasuk bagi mereka yang menuntut ganti rugi.

\section{Hak untuk mendapatkan kompensasi ganti} rugi dan/atau penggantian apabila barang dan/atau jasa yang diterima tidak sesuai dengan perjanjian atau tidak sebagaimana mestinya

Hak atas ganti kerugian ini dimaksudkan untuk memulihkan keadaan yang telah menjadi rusak (tidak seimbang) akibat adanya penggunaan barang dan/atau jasa yang tidak memenuhi harapan konsumen. Hak ini sangat terkait dengan penggunaan produk yang telah merugikan konsumen, baik yang berupa kerugian materi, maupun kerugian yang menyangkut diri (sakit, cacat, bahkan kematian) konsumen. ${ }^{18}$

Jika konsumen merasakan, kuantitas dan kualitas barang dan/atau jasa yang dikonsumsinya tidak sesuai dengan nilai tukar yang diberikannya, ia berhak mendapatkan ganti kerugian yang pantas. Jenis dan jumlah ganti kerugian yang berlaku atau atas kesepakatan masing-masing.

Pasal 45 ayat (2) UU Nomor 14 tahun 1992 Tentang Lalu Lintas dan Angkutan Jalan menyebutkan bahwa :

Besarnya ganti rugi sebagaimana dimaksud dalam ayat (1) adalah sebesar kerugian yang secara nyata diderita oleh penumpang, pengirim barang, atau pihak ke-3.

Berdasarkan pada penggantian ganti rugi maksimal 10x biaya pengiriman, tentang pemberian ganti kerugian untuk barang yang rusak atau hilang sebagian, apabila dikaitkan dengan pendapat Ahmadi Miru dan Shidarta serta berdasarkan hasil wawancara tentang tata cara

\footnotetext{
${ }^{18}$ Ahmadi Miru dan Sutarman Yodo, Op.cit, hlm.44
} 
mengajukan ganti kerugian maka dapat dideskripsikan bahwa PT. Kerta Gaya Pusaka Perwakilan Purwokerto dalam kegiataannya telah memenuhi hak konsumen untuk mendapatkan kompensasi, ganti rugi dan/atau penggantian apabila barang dan/atau jasa yang diterima tidak sesuai dengan perjanjian atau sebagaimana mestinya seperti tercantum pada ketentuan Pasal 4 butir h UUPK.

\section{E. Penutup}

\section{Simpulan}

Berdasarkan hasil penelitian dan pembahasan data yang dilakukan, maka dapat disimpulkan bahwa PT. Kerta Gaya Pusaka Perwakilan Purwokerto sebagai badan usaha yang mengelola jasa pengiriman paket termasuk dokumen, dalam memberikan perlindungan hukum terhadap konsumen belum melaksanakan sepenuhnya ketentuan yang tercantum dalam UUPK.

Hak konsumen dalam Pasal 4 UUPK yang sudah dipenuhi oleh PT. Kerta Gaya Pusaka Perwakilan Purwokerto adalah sebagai berikut:

a. Hak atas kenyamanan, keamanan, dan keselamatan dalam mengkonsumsi barang dan/atau jasa

PT.Kerta Gaya Pusaka sudah memberikan kenyamanan, keamanan, dan keselamatan terhadap barang paket yang diangkutnya, hal ini terrdapat dalam kewajiban pengangkut untuk menjaga keamanan dan keselamatan barang yang diangkut, serta Pasal 14 Peraturan Menteri Perhubungan No. KM 5 Tahun 2005 Tentang Penyelenggaraan Jasa Titipan.

b. Hak untuk memilih barang dan/atau jasa serta mendapatkan barang dan/atau jasa tersebut sesuai dengan nilai tukar dan kondisi serta jaminan yang dijanjikan.

Dalam perjanjian yang berbentuk konosemen antara konsumen dengan PT. Kerta Gaya Pusaka, penandatanganan yang dilakukan konsumen tidak ada unsur paksaan dari luar, konsumen bersediamenaati isian dan syarat-syarat pengiriman. c. Hak atas informasi yang benar, jelas, dan jujur mengenai kondisi dan jaminan barang dan/atau jasa.

PT. Kerta Gaya Pusaka menetapkan tarif pengiriman berdasarkan Surat Pemberitahuan yang dikeluarkan oleh PT.Kerta Gaya Pusaka Perwakilan Purwokerto tertanggal 30 November 2005, serta informasi mengenai adanya tanggung jawab dari pengangkut

d. Hak untuk didengar pendpat dan keluhannya atas barang dan/atau jasa yang digunakan PT.Kerta Gaya Pusaka memberikan waktu $2 \times 24$ jam terhitung mulai barang diterima kepada konsumen untuk melaporkan apabila terdapat keluhan mengenai barang yang diterimanya.

e. Hak untuk mendapatkan kompensasi, ganti rugi dan/atau penggantian, apabila barang dan/atau jasa yang diterima tidak sesuai dengan perjanjian.

f. Hak untuk diperlakukan atau dilayani secara benar dan jujur serta tidak diskriminatif.

\section{Saran}

PT. Kerta Gaya Pusaka Perwakilan Purwokerto sebagai badan usaha yang menyelenggarakan jasa pengiriman dokumen seyogyanya berupaya untuk selalu menerapkan ketentuan dalam UUPK, hendaknya semua hak-hak konsumen dapat dipenuhi sesuai yang diamanatkan dalam UUPK.

\section{Daftar Pustaka}

Miru, Ahmadi dan Sutarman Yodo. 2004. Hukum Perlindungan Konsumen. Jakarta: PT. Gaja Grafindo Persada;

Muhammad, Abdulkadir. 1982. Hukum Perikatan. Bandung: Alumni;

1991. Hukum Pengakutan Darat, Laut dan Udara. Bandung: Citra Aditya Bakti;

Nasution, A.Z. dkk. 2001. Liku-Liku Perjalanan UUPK. Jakarta: YLKI

........... 2002. Hukum Perlindungan Konsumen; Suatu Pengantar. Jakarta: Diadit Media;

R, Setiawan. 1999. Pokok-Pokok Perikatan. Bandung: Putra Bardin; 
Penerapan Pasal 4 UU No.8 Tahun 1999 Tentang Perlindungan 153

Konsumen Pada Jasa Pengiriman Dokumen ...

Shidarta. 2004. Perlindungan Konsumen Indonesia. Jakarta: PT. Gramedia Widiasarana Indonesia;

Soekardono. 1986. Hukum Dagang Indonesia Jilid II. Jakarta: CV.Rajawali;

Tjakranegara. Soegiyatna, 1995. Hukum Pengangkutan Barang dan Penumpang. Jakarta: Rineka Cipta;

Yani, Ahmad dan Gunawan Widjaya. 2003. Hukum Tentang Perlindungan Konsumen. Jakarta: PT. Gramedia Pustaka Utama. 